\title{
Evaluating the Activities of Festival on Surface Water Quality in Ugep, Cross River State, Nigeria
}

\author{
Ej Eja Iwara (Corresponding Author) \\ Department of Tourism Studies, University of Calabar, Nigeria \\ E-mail: ejaiwara43@gmail.com
}

Ebin Okah Inah

Department of Geography and Environmental Sciences, University of Calabar, Nigeria

E-mail: ebin.inah@gmaill.com

Received: November 7, 2018 Accepted: March 4, 2019 Published: March 7, 2019

doi: $10.5296 /$ jsss.v6i2.14468

URL: https://doi.org/10.5296/jsss.v6i2.14468

\begin{abstract}
The study aim at evaluating the activities of festival on surface water quality in Ugep, Yakurr Local Government Area of Cross River State, Nigeria. Four streams where identified and water quality analysis was carried out for three days. Four hundred copies of questionnaire were randomly distributed to residents during the festival period to capture the socio-economic variables such as the benefits and the problems that are associated with the festival. The result presented in table one, two and three show a high permeable values above the WHO permeable limit since the result presented in one to three show a high values above the WHO bench mark it's therefore indicating that the festival has negative impact on the surface water quality in the study area. The result from the socio-economic variables shows that even though the festival has contributed socio-economically to the wellbeing of the indigenous people, there are problems that are associated with festival activities that needs urgent attention. It is on this premise that all the stakeholders involved in the organization of the festival event must provide a mechanism that would avert the impact of the festival activities on surface water quality and other socio-economic problems in the area.
\end{abstract}

Keywords: Activities, festival, surface water, quality stream

\section{Introduction}

Festivals are tourism events that have impacted both positive and negative in most tourism 
destinations due to the socio-economic activities that is usually witness during the event (Eja, 2011). Ugep community is one of the tourism destination in Cross River State owing to its unique cultural and tourism attraction in the area. The people of Ugep celebrate "Leboku" a new yam festival which is internationally recognized and has attracted several visitors arrival to the area (Eja \& Mary, 2018). The festival as a tourism event usually celebrated at Ugep the headquarters of Yakurr local government area and is accompanied with high socio-economic activities which impacted negatively on the community and its environs especially surface water quality.

Water quality of streams are good from their place of origin (source) and get degraded in quality as they pass through towns, cities and communities as the case may be due to wastes discharge on it from human activities like agricultural activities, influence from other industrial activities and other wastes discharge on it directly without treatment (Ukwayi, Eja, \& Felix, 2012). Streams in Ugep community get contaminated as it flows across the community due to festival activities and other corresponding activities from human activities that leads to changes in the physico-chemical and bacteriological quality parameters, the streams take its course from a basement complex rocks in the adjourning community like Mkpani.

The tremendous impact recorded by the Ugep festival in terms of increase in the rate of visitors arrivals, increase in emergence of tourism support services, increase in income and revenue generation to both the local people and government and even employment (Osonwa $\&$ Eja, 2015). The festival activities are not devoid of socio-economic problems such as inflation, increase in prostitution and increase in demand for housing, congestion and increase in crime rate (Eja \& Violet, 2015). The idols used for the festival are submerged into the water bodies, idols are constructed by plastics, clay, native chalk of different colours can negatively altered the streams water quality parameters like Do, Turbidity, BOD levels also lead to death of living organisms in the water bodies. Besides, the festival is usually accompanied with high waste generation from socio-economic activities which eventually is discharge into the surface water such as streams, and spring through surface run off during heavy rains. Furthermore, the discharge of wastes into the surrounding surface water has contaminated the existing surface water which serve as the major sources of domestic water supply which the indigenous people solely depend upon for their livelihood sustenance. It is on this note that this research evaluate the effect of festival activities on water quality in Ugep, Yakurr Local Government Area, Cross River State, Nigeria.

\section{Literature Review}

\subsection{Challenges of Surface Water Quality}

Odoemelam and Oko (2013) published a paper on the physico-chemical parameters and heavy metal content of water, fish and sediments of Cross River at Afikpo North Local Government Area of Ebonyi State, Nigeria. The study revealed that physico-chemical parameters and heavy metals content of the river was determined using standard methods. The results revealed that the water is acidic in nature in point 1 (ph 6.80) and slightly alkaline in point 4 (pH 7.47). Turbidity ranged 16FTU in (point 4) to 22.0 FTU (in point 1) with the mean value of 19.250 FTU. The dissolved oxygen rage of 5.16 (point 2) to 8.0 (point 4) and iron was the most abundant metal both in sediment $(99.78 \mathrm{mg} / \mathrm{kg})$, fish $(11.45 \mathrm{mg} / \mathrm{kg})$ and 
water $(4.85 \mathrm{mg} / \mathrm{l})$ and calcium was the lowest concentration in water $(0.19 \mathrm{mg} / \mathrm{kg})$ while $\mathrm{Zn}$ and NI was the lowest in Fish $(0.18 \mathrm{mg} / \mathrm{kg})$ and sediment $(1.55 \mathrm{mg} / \mathrm{kg}$ and in all the heavy metals was higher $(\mathrm{P}<0.05)$ in sediment than in fish and water respectively.

Etim and Obo (2014) examined the spatial and temporal variations in the physico- chemical characteristics of stubbs Creek Niger Delta, Nigeria and the result of the study revealed that water quality samples were analyzed with the follows results: temperature $\left(24.29{ }^{\circ} \mathrm{C}\right)$ turbidity 3.6-115.7NTU, electric conductivity 1045.9380 us/cm, salinity 1-13.6 percent, Alkalinity 18-5.884 mgr, total suspended solids 1-14.4821 mg, dissolved oxygen 32-7.70 mgl, biochemical oxygen demand 1.1-34 mgr and transparency 0.3-1.75 $\mathrm{m}$ and established that in all the parameters measured turbidity, salinity, alkalinity and total suspended solid show significant variation $(\mathrm{P}<0.05)$ spatial variation temperature, turbidity alkalinity biochemical oxygen demand, phosphate, magnesium and $\mathrm{pH}$ show significant variation of $(\mathrm{P}<0.05)$ seasonal variation the study shows that the level of turbidity, electrical conductivity, calcium and magnesium are above the permissible limits showing that there is environmental pollution in the study area.

Tubonimi, Omubo and Herbert (2010) assessed water quality along Amadi Creek in Port Harcourt, Nigeria. The quality of water from Amadi creek was assessed using standard methods with the view of determining the level of pollution and the effect of anthropogenic activities. The results of the analyses of the water samples showed low nutrient levels with ranges of dissolved oxygen (4.87-15.42 mg/1), $\mathrm{pH}$ (6.73-7.33), alkalinity (76-90 mg/1), electrical conductivity (20000-36100 pS/cm), total dissolved solids $(14000-25270 \mathrm{mg} / 1)$, chloride (3211-9682 mg/1), Sulphate (382.44-2107.32 mg/1), phosphate $(0.05 \mathrm{mg} / 1)$, nitrate (0.11-0.26 mg/1), total hardness (2880-2352 mg/1), Biochemical oxygen demand (3.25-12.99 $\mathrm{mg} / 1), \mathrm{Ca}^{2+}(192-384.0 \mathrm{mg} / 1), \mathrm{Mg}^{2+}(433.34-1358.59 \mathrm{mg} / 1)$ and BOD-N03 ratio of 28.2. Dry season levels of the parameters were generally higher than wet season levels. The difference between them was statistically significant $(\mathrm{P}<0.05)$. The levels of EC, BOD, TDS, TH, Ca"', $\mathrm{Mg}^{2+}, \mathrm{SO}^{\wedge} "$ and $\mathrm{CI}$ exceeded permissible limits which pose serious environmental concern. The water was classified as brackish, saline, hard, nearly polluted and not potable.

Oluyemi, Adekunle, Adenuga, and Makinde (2010) conducted a study on physico-chemical properties and heavy metal content of water sources in Ife North Local Government Area of Osun State, Nigeria. Results of their study showed that from temperature range of 26.5 to $33.0{ }^{\circ} \mathrm{C}, \mathrm{pH}$ (6.53 to 8.90$)$, conductivity $\left(63.0\right.$ to $\left.1039.0^{\prime} \mu \mathrm{S} / \mathrm{cm}\right)$, resistivity $(0.00$ to $\left.0.02 \mathrm{~m} \_. c m\right)$, salinity $(300.00$ to $700.00 \mathrm{mg} / \mathrm{L})$, total solids $(90.00$ to $1175.00 \mathrm{mg} / \mathrm{L})$, total dissolved solids (37.80-622.50 mg/l), suspended solids (34.50 to $794.00 \mathrm{mg} / \mathrm{L})$, dissolved oxygen (4.48 to $9.48 \mathrm{mg} / \mathrm{L})$, Biological Oxygen Demand (BOD5) (0.69 to $6.74 \mathrm{mg} / \mathrm{L}$ ), chloride (3.64 to $184.04 \mathrm{mg} / \mathrm{L})$, Nitrate (1.08 to $53.03 \mathrm{mg} / \mathrm{L}$ ), phosphate $(4.99$ to $23.07 \mathrm{mg} / \mathrm{L}$ ) and sulphate (6.02 to $28.95 \mathrm{mg} / \mathrm{L}$ ). Results of Atomic Absorption spectrophotometric analysis (AAS) of samples for dissolved trace metals; ( $\mathrm{Cd}, \mathrm{Pb}, \mathrm{Mn}, \mathrm{Zn}, \mathrm{Cu}, \mathrm{Cr}$ and $\mathrm{Fe}$ ), showed mean metal concentration to vary widely depending on the source of the water sample as follows: $\mathrm{Pb}(0.29 \pm 0.05$ to $6.69 \pm 0.53 \mathrm{mg} / \mathrm{L}), \mathrm{Cd}(0.77 \pm 0.06$ to $2.24 \pm 0.08 \mathrm{mg} / \mathrm{L}), \mathrm{Zn}(0.03 \pm 2.15$ to $0.22 \pm 4.64 \mathrm{mg} / \mathrm{L}), \mathrm{Cu}(0.18 \pm 16.34$ to $0.41 \pm 5.00 \mathrm{mg} / \mathrm{L}), \mathrm{Fe}(6.00 \pm 0.21$ to $31.75 \pm 0.80$ $\mathrm{mg} / \mathrm{L})$ and $\mathrm{Mn}(0.14 \pm 6.12$ to $0.23 \pm 99.11 \mathrm{mg} / \mathrm{L})$. The results obtained for the physical parameters agreed with the limits set by both national and international bodies for drinking 
and domestic water with few exceptions.

Udousoro and Umoren (2014) assessed surface and ground water quality in Uruan in Akwa Ibom State. The water quality status of rivers, streams, and ground water in Uruan Local Government Area, Nigeria was investigated as the inhabitants of this region depend on these water resources for drinking and other purposes. The results were compared with water quality standards of the World Health Organisation (WHO) and the Nigerian Standard for Drinking Water Quality (NSDWQ). Most quality determinands were within WHO guidelines except $\mathrm{pH}, \mathrm{EC}$, turbidity, TDS, total coliform, and Fe. The overall ionic dominance pattern for the river, stream, borehole and well follow the same trend $\mathrm{Fe}>\mathrm{Na}>\mathrm{Mn}>\mathrm{K}$ and $\mathrm{Cl}^{-}>\mathrm{NO}_{3}$ $->\mathrm{NO}_{2}{ }^{-}$. The hygienic condition of the water bodies is found to be poor. High BOD5, coliform count and BOD5:N03 ratio of river, stream and ground water samples are indicative of organic pollution due to faecal contamination. PCA reveals 3 extracted principal components (PCs) by river water, 6 PCs each by both stream and ground water; with the sources of pollution.

\section{Materials and Method}

The study aim at evaluating the activities of festival on surface water quality in Ugep, Yakurr local government area of Cross River State, Nigeria. A reconnaissance survey was carried out where four streams were identified like Isayi stream, Mma Oden stream, kewel stream and Edim Kokol stream. Water samples were collected on the streams for three days, composite sampling method was adopted for the period under review, which is three days in the month of August, 2017. And the collected water samples where preserved using standard beach mark of ALPH, 2010 and transported to the laboratory for analysis.

Water samples were collected in the four streams once a day for three days putting into consideration that these are the days of the festival peak. Meanwhile, the study considered the physic-chemical and bacteriological parameters. This research was conducted in Ugep the headquarter of Yakurr local government area. Four hundred (400) copies of questionnaire were distributed to residents in Ugep using random sampling technique in questionnaire administration. The rationale for using the random sampling was to allow every member of the target population equal opportunity of being selected for this study. The questionnaire was used to obtain information such as socio-demographic characteristics of the people, festival activities, prospects and challenges associated with the festival. Materials used in making idols has contaminated water quality in the world during festival activities and it has impacted greatly on water quality and reducing the oxygen content in water, and the physical-chemical and bacteriological parameter of streams (Rajeer, 2016). These streams were purposively selected because these are the major water sources in Ugep which the inhabitants of the study area carried out their daily activities (Ebin, 2016).

One hypothesis was stated which try to evaluate whether or not exist the relationship between the activities of the festival and the benefits associated with the festival and was tested using the Pearson product moment correlation which try to evaluate relationship between two variables. 


\section{Mll Macrothink}

\section{Findings}

\subsection{The Festival Activities in the Area}

The various cultural activities performed during the Ugep festival presented in Figure 1 shows that display of farm products and war dance were the most cultural activities performed during the Ugep festival as observed with values of 14 percent and 13 percent respectively. Figure 1 revealed that beauty queen competition and youth display were also the cultural activities in Ugep festival with a value of 11 percent and 10 percent. Hunting dance and local wrestling were the least cultural activities performed during the festival with values of 7.3 percent and 7 percent respectively.

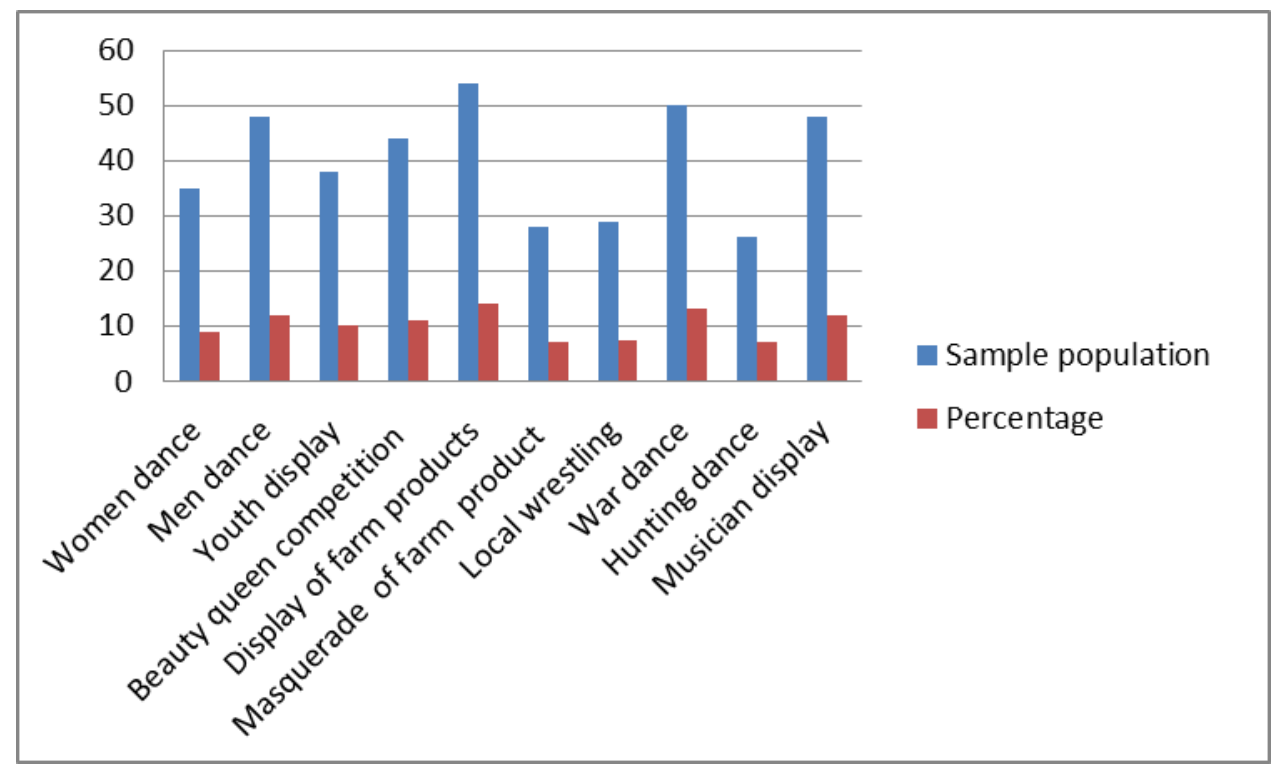

Figure 1 . The festival activities in the area

Source: Field survey (2017).

\subsection{Contamination of Water Resources}

Contamination of water sources (streams) occurs as a result of discharges of sewage from domestic and festival waste without proper treatment which results to changes of streams water quality parameters.

Table 1 shows results of water quality parameters from day one of the four streams, Kewel stream, Isayi stream, Mma Oden and Edem Kokol stream with WHO bench mark showing significant difference of the streams and WHO limit indicating that festival activities has impacted on the water quality parameters of streams in the study area. 
Table 1. Results of water quality parameters from day one

\begin{tabular}{llllll}
\hline Parameters & Isayi & Kewel & Mma Oden & Edim Kokol & WHO limit \\
\hline T. Coliform & 9 & 5 & 6 & 10 & 0 \\
F. Coliform & 2 & 1 & 2 & 1 & 0 \\
BoD & 1.5 & 1.6 & 1.4 & 1.5 & 6 \\
Do & 3.5 & 3.6 & 3.3 & 3.7 & 0 \\
Sp. Conductivity & 66 & 74 & 15 & 68 & 2000 \\
Fe & 0.269 & 0.412 & 0.298 & 0.312 & \\
$\mathrm{SO}_{4}$ & 3.362 & 3.127 & 3.178 & 3.342 & \\
$\mathrm{PO}_{4}$ & 0.004 & 0.008 & 0.007 & 0.003 & 0 \\
$\mathrm{NH}_{4}$ & 0.568 & 0.531 & 0.518 & 0.516 & $45 \mathrm{ppm}$ \\
$\mathrm{pH}$ & 6.78 & 6.41 & 6.32 & 6.33 & $6.5-8.5$ \\
$\mathrm{Mn}$ & 0.021 & 0.024 & 0.012 & 0.013 & $150 \mathrm{ppm}$ \\
$\mathrm{Zn}$ & 0.020 & 0.023 & 0.013 & 0.021 & 15 \\
\hline
\end{tabular}

Source: Field survey (2017).

Table 2 shows results of water quality parameters for day two of the four streams indicating that there is significant variations on the water quality parameters and WHO limit showing that the activities of festival has impacted on the water quality parameters of the mentioned streams in the study area.

Table 2. Results of water quality parameters from day two

\begin{tabular}{|c|c|c|c|c|}
\hline Parameters & Lebesone stream & Lobow stream & Edim Kokol & Kewel stream WHO limit \\
\hline T. Coliform & 9 & 10 & 6 & 6 \\
\hline F. Coliform & 2 & 4 & 3 & 4 \\
\hline BoD & 1.4 & 1.3 & 1.5 & 1.6 \\
\hline Do & 3.4 & 3.5 & 3.7 & 3.6 \\
\hline Sp. Conductivity & 74 & 75 & 76 & 78 \\
\hline $\mathrm{Fe}$ & 0.286 & 0.278 & 0.297 & 0.313 \\
\hline $\mathrm{SO}_{4}$ & 3.127 & 3.135 & 3.134 & 3.142 \\
\hline $\mathrm{PO}_{4}$ & 0.005 & 0.008 & 0.004 & 0.007 \\
\hline $\mathrm{NH}_{4}$ & 0.570 & 0.571 & 0.532 & 0.528 \\
\hline $\mathrm{pH}$ & 6.81 & 6.75 & 6.51 & 6.43 \\
\hline $\mathrm{Mn}$ & 0.014 & 0.022 & 0.013 & 0.025 \\
\hline $\mathrm{Zn}$ & 0.024 & 0.021 & 0.022 & 0.023 \\
\hline
\end{tabular}

Source: Field survey (2017).

Table 3 shows results of water quality parameters for day three of the four streams with WHO permissible limit showing significant differences between the streams and WHO showing that the festival activities has greatly impacted on the streams water quality parameters in the study area. 
Table 3. Results of water quality parameters from day three

\begin{tabular}{|c|c|c|c|c|c|c|}
\hline Parameters & Unit & $\begin{array}{l}\text { Lebesong } \\
\text { stream }\end{array}$ & $\begin{array}{l}\text { Kewel } \\
\text { stream }\end{array}$ & $\begin{array}{l}\text { Loblow } \\
\text { Stream }\end{array}$ & $\begin{array}{l}\text { Edim } \\
\text { stream }\end{array}$ & Kokol WHO \\
\hline T. Coliform & Idomi & 7 & 8 & 5 & 9 & \\
\hline F. Coliform & Idomi & 3 & 2 & 1 & 2 & \\
\hline BoD & Mgl-1 & 1.5 & 1.4 & 1.5 & 1.6 & \\
\hline Do & Mgl-1 & 3.5 & 3.5 & 3.6 & 3.5 & \\
\hline Sp. & Mgl-1 & 75 & 74 & 77 & 76 & \\
\hline \multicolumn{7}{|l|}{ Conductivity } \\
\hline $\mathrm{Fe}$ & Mgl-1 & 0.314 & 0.255 & 0.422 & 0.289 & \\
\hline $\mathrm{SO}_{4}$ & Mgl-1 & 3.136 & 3.233 & 3.128 & 3.328 & \\
\hline $\mathrm{PO}_{4}$ & Mgl-1 & 0.007 & 0.008 & 0.005 & 0.005 & \\
\hline $\mathrm{NH}_{4}$ & Mgl-1 & 0.660 & 0.560 & 0.541 & 0.517 & \\
\hline $\mathrm{pH}$ & Mgl-1 & 6.82 & 6.77 & 6.45 & 6.34 & \\
\hline $\mathrm{Mn}$ & Mgl-1 & 0.015 & 0.022 & 0.027 & 0.014 & \\
\hline $\mathrm{Zn}$ & & 0.023 & 0.023 & 0.021 & 0.023 & \\
\hline
\end{tabular}

Source: Field survey (2017).

The community perception on the socio-economic benefits of the Leboku New Yam festival presented in Figure 2 shows that all the mentioned variables are the socio-economic benefits of the Ugep festival as observed with a value of 33 percent followed by increase in income generation with a value of 18 percent. It was also noticed in Figure 2 that employment generation and increase in cortage industries were also the socio-economic benefits of the Leboku New Yam festival in Ugep as observed with a value of 14.3 percent and 9 percent respectively.

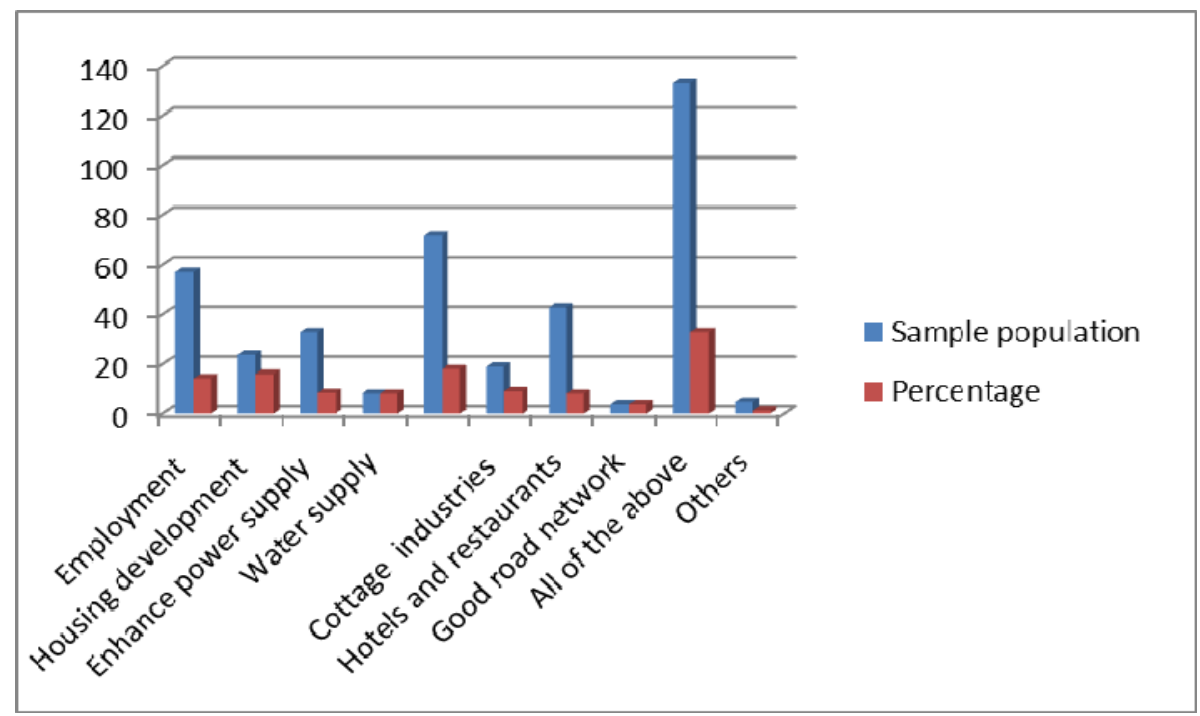

Figure 2. Community perception on the socio-economic benefits of Leboku new yam festival Source: Field survey (2017). 


\section{Ml Macrothink}

\subsection{Socio-Economic Problems}

The socio-economic problems associated with Ugep festival presented in Table 4 shows that waste generation and high level of youth disobedience to elders were the major socio-economic problems associated with the festival event with values of 23.3 percent and 15 percent. It was also noticed in Table 4 that increase in divorce or broken homes and increase in prostitution were also problems associated with the festival event in the area as observed with values of 12.3 percent and 9.5 percent while diffusion of culture was the least problem associated with the Ugep festival event in the area.

Table 4. Socio-economic problems of the festival

\begin{tabular}{llll}
\hline s/no & Socio-economic problems & Sample population & Percentage \\
\hline a. & Increase in crime rate & 18 & 4.75 \\
b. & Increase in prostitution & 33 & 9.5 \\
c. & High level of youth disobedient to elders & 59 & 15.00 \\
d. & Increase in divorce & 49 & 12.3 \\
e. & Diffusion of culture & 23 & 5.8 \\
f. & Increase in inflation & 30 & 7.5 \\
g. & Congestion & 33 & 8.3 \\
h. & Increase in waste generation & 89 & 22.3 \\
i. & All of the above & 43 & 10.8 \\
j. & Others & 17 & 4.3 \\
& Total & 400 & 100 \\
\hline
\end{tabular}

Source: Field survey (2017).

The result from the stated hypothesis which try to examine whether or not exist significant relationship between the festival activities and the benefits associate with the festival in the area. While alternate hypothesis $\left(\mathrm{H}_{1}\right)$ states that there is a significant relationship between the festival activities and the benefits associated with the festival in the area. The result obtained presented in Table 5 shows t-calculated value of 0.51 greater than the r-calculated value of 0.51 greater than the $t$-calculated value of 0.23 indicating that there is a positive correlation between the festival activities and the benefits associated in the area. However, since the calculated value is greater than the festival, the null (Ho) hypothesis is therefore rejected while the alternate $\left(\mathrm{H}_{1}\right)$ is accepted indicating that there is a significant relationship between the two variables. 
Table 5. Result analysis of hypothesis one showing the relationship between the festival activities and the socio-economic problem

\begin{tabular}{llll}
\hline & & Cultural activities Socio-economic problems \\
\hline Festival activities & Pearson Correlation & 1 & $1215^{* *}$ \\
& Sig. (2-tailed) & & .142 \\
& N & 9 & \\
\multirow{5}{*}{ Socio-economic problems } & Pearson Correlation & $.514^{* *}$ & 1 \\
& Sig. (2-tailed) & .142 & \\
& N & 8 & 8 \\
\hline
\end{tabular}

Source: Data analysis (2017).

\section{Discussion of Discussion of Findings}

This research examined the activities of festival activities on surface water quality in Ugep, Yakurr local government area of Cross River State- Nigeria. Data that were used for the study was basically water quality parameters for four streams in Ugep community were the festival was celebrated for three days in Ugep. Water quality parameters that were measured are total coliform, feacal coliform, BoD, Do, Sp. Conductivity, Fe, $\mathrm{SO}_{4}, \mathrm{PO}_{4}, \mathrm{NH}_{4}, \mathrm{pH}, \mathrm{Mn}$ and $\mathrm{Zn}$. And from the results of the water quality analysis, it shows that significant differences exist in water quality of streams and WHO bench mark for domestic water uses. Significant differences exist between streams with WHO and all the parameters values above the WHO permissible limits. And this has colloborated result elsewhere with that of Ekpoh, Ebin and Efiong (2010) on the effects of human activities on water quality of Lokpol stream in Yakurr local government area of Cross River State and that of Rajeer (2016) on the assessment of water quality in river Yamuna during Idol immersion that is idol immersion activities during festival period has negative impact on the water quality of river Yamuna. According to Rajeer (2016), the physico-chemical parameter of the river is affected to a greater extent and resulted to the attraction in the physical and biological composition of water in the river and the water quality.

\section{Conclusion}

The Ugep festival has witness tremendous impact and has sustained the livelihood of most residents and the indigenous people in the area. The festival from the data obtained show that several socio-economic activities are usually performed to make the event such as dancing play of tourism products and other competitions. The data collected indicate that the festival event despite it positive impact to the indigenous community, it activities are accompanied by socio-economic problems such as prostitution, inflation, increase in crime rate, congestion and high waste generation. It was noticed from the data obtained show that out of the problems that were associated with the festival, waste degeneration constitute a major problem which is usually discharge into the surrounding surface water such as streams, and so on especially during surface runoff. The data obtained from the analyses of the water quality revealed that wastes discharge into the surface water has polluted and contaminated the surface waters which serve as the only source of domestic water in the area. 


\section{Recommendations}

The increase in socio-economic activities during the festival which have contaminated the surface water quality in the area need urgent attention. It is on this premises that the following recommendations are hereby put forward to avert the menace caused by the festival activities in the areas.

1) The indigenous community should provide adequate waste disposal equipment. This would help to reduce indiscriminate waste disposal which are usually eroded during surface run-off

2) The community should set up a taskforce that would regulate the rate of waste generation and how they will be collected on daily bases.

3) The community should set up agencies that would be responsible for waste disposal especially during the festival event.

4) The community should provide a dumpsite where the collected waste can be deposited. This would help to reduce the amount of waste discharge indiscriminately in the surrounding surface water bodies in the area.

\section{References}

ALPH. (2010). Standard methods for the examination of water waste (7th ed.). Washington DC: America Public Health Association.

Ebin, O. I. (2016). Domestic water quality in relation to waterborne diseases in Yakurr local government of Cross River State - Nigeria. Unpublished thesis.

Eja, E. I. (2011). As assessment of the relevance of Christmas festival in the development of sustainable hospitality industry in Calabar city. African Journal of Social Science, 1(3), 1-9.

Eja, E. I., \& Iji Mary, E. (2018). Visitors arrivals and destination development: A case study of selected recreation resorts in Cross River, Nigeria. European Journal of Research in Social Sciences, 6(3).

Eja, E. I., \& Violet, E. A. (2015). The influence of Leboku new yam festival on catchment communities in Yakurr local government area. American Journal of Tourism Research, 4, 37-43.

Ekpoh, J., Ebin, O., \& Efiong, J. (2010). Effects of human activities on water quality of Lokpol stream in Yakurr Local government area of Cross River State, Nigeria.

Etim, L., \& Obo, O. I. (2014). Spatial and temporal variations in the physicochemical characteristics of stubbs Creek, Niger Delta, Nigeria. Nigeria Journal of Agricultural, Food and environment, 10(4), 64-74.

Odoemelam, S. A., \& Oko, I. O. (2013). Physicochemical parameters and heavy metal content of water, fish and sediment from Cross River a Afikpo north local government area of Ebonyi state, Nigeria. Bioresearch Bulletin Sapience Research Labs.

Oluyemi, E. A., Adekunle, A. S., Adenuga, A. A., \& Makinde, W. O. (2010). Physico-chemical properties and heavy metal content of water sources in Ife North Local Government Area of Osun State, Nigerian. African Journal of Environmental Science and Technology, 4(10), 691-697.

Osonwa, D. K. (2015). Assessing tourists arrivals as a catalyst for employment and income 
generation in Calabar, Nigeria. Research on Humanities in Social Sciences, 5(9), 37-43.

Rajeer, K. M. (2016). Assessment of water quality in River Yamuna during Idol immersion, Journal of Ecology and Environmental Science, 2347-7830.

Tubonimi, J. K. I., Omubo, A., \& Herbert, O. S. (2010). Assessment of water quality along Amadi Creek in Port Harcourt, Nigeria. Scientia Africana, 9(1), 150-162.

Udousoro, I., \& Umoren, I. (2014). Assessment of surface and ground water quality of Uruan in Akwa Ibom State of Nigeria. Journal of Natural Sciences Research, 4(6), 11.

Ukwayi, J. K., Eja, I. E., \& Ojong, F. (2012). The challenges and prospects of oil companies activities on communities in AKS. Global Journals of human social sciences Inc.

WHO. (2005). Emerging issues in water \& infectious disease organization. Geneva, Switzerland.

\section{Copyright Disclaimer}

Copyright for this article is retained by the author(s), with first publication rights granted to the journal.

This is an open-access article distributed under the terms and conditions of the Creative Commons Attribution license (http://creativecommons.org/licenses/by/3.0/). 